\title{
Relative Effects of Problem-Solving and Concept Mapping Instructional Strategies on Student's Achievement in Economics
}

\author{
Adu, E. Olusola (PhD) \& B. O. Emunemu (PhD)
}

\section{Abstract:}

This paper examines the relative effects of problem-solving and concepts mapping instructional strategies on students' achievement in economics. The definition of economics as a concept was discussed. The reasons for acceptance of Economics as a subject in secondary school were also looked into. The paper discussed various types of teaching strategies and they can aid the academic achievement of students in Economics. Also problem-solving and concept mapping strategies are also discussed and their significance and importance to students.

The research design employed a $3 \times 2$ pre test, post test, control group, quasi experimental. The result of the analysis showed that there was no significant main effect of the treatment on students' achievement in Economics. $\left(F_{(2.50)}=\right.$ $1.517, P>.05)$. It is obtained that the main effect of gender on students' achievement in Economics is not significant. $\left(F_{(1,50)}=.502 ; P>.05\right)$. However the two way interaction effect of treatment and gender is not significant $\left(F_{(1.50}=.585\right.$, $P>.05)$.

It was however recommended that teachers should be trained in the used of learner centered instructional strategies such as problem solving. The periodic use of such and other innovative strategies will promote high-level learning. 
Relative Effects of Problem-Solving \& Concept Mapping ...

Teachers should pay attention to the training of their students in the development of problem solving skills before the end of SSCE Programme

\section{Introduction:}

The purpose of teaching at any level is to produce certain desirable changes in the learner. Such changes may be in the form of acquiring intellectual skills, solving problems and inculcation of desirable attitudes and values.

Although education goes on in all aspects of human endeavour, most societies have set up specific institutions that use a variety of means to promote efficient and desirable learning. In these institutions, usually the major concern of learners and teachers in the acquisition of what is considered to be world while knowledge by the students. The responsibility of importing this knowledge resolves around the teacher

The recent changes in the world and within nations have brought about changes in educational goals. The school are called not only to equal the learner with basic knowledge of economics context but also with higher cognitive skills, such as problems solving and thinking skills, mental cognitive skills that allow for self-development and continuous hearing skills, economics is not left out in this change.

In response to these changes, there is movement away from behaviorist method of direct teaching (such as in lecture method, not copping and dictation) where the learner is given contents to memorize and regurgitate to constructive instructional models where the learners are required to produce and use knowledge. In ideal situation, both approaches are often combined. 
The role of the teacher is drastically shifted from that of imparting knowledge as facilitator. Facilitation is like a football coach. The coach does not play the football for players but he/she provides the necessary environment for them to play, providing correction and feedback when necessary. The teacher provides the learners with basic knowledge, values and skills but allows them to go through the process of constructing knowledge. The learners are therefore given complete autonomy and allowed to initiate and complete learning with minimal teacher interference.

However, there are many learner centered strategies but for this paper problem-solving and concept mapping instructional strategies will be used.

Economics came into secondary school curriculum in the mid-sixties after a long protracted debate of the subject matter (Obemeata 1989). The needs for teaching the subject arouse out of what Szreter (1975) observed. Feeling that a secondary school leaver must be adequately prepared, regretting that a secondary school leaver could not have been adequately prepared for life in the modern society without understanding of basic economic topics, such as inflation, national income, population among others.

Onimode (1994) while commenting on the significance of economics education to any nation, said it is a necessity for both leaders and citizens to understand basic economic concepts and principles well enough to enable them to understand, appreciate and seek to improve the economic situation to face up to public economic question and to use their knowledge for their own social good.

Obemeata (1992) say that economics as a subject has various values to the learners and this is one of the reasons 
Relative Effects of Problem-Solving \& Concept Mapping ...

for studying economics in secondary school. The values according to him include: The cultural value, Intellectual Training and Vocational Training.

\section{Acceptance of Economics}

As a result a combination of factors from within and outside Nigeria, economics gradually came to be accepted as subject that can be taught in secondary schools from midsixties. In Britain, people came to appreciate the civic and educational values of economics According to Szreter (1975), it was felt that a secondary school leaver could not be said to have been adequately prepared for life in the modern world, if he could not appreciate such economics topics as inflation, national income, population and banking etc. Also it was recognized that it contributed immensely to the intellectual development of its recipients. A great educational value was attached to what had been termed the economics way of thinking, a mode of considering a variety of problems that are far from being easy to define.

ITUAH, (2003) examines 10 schools, 6 mixed schools 2 male schools and 2 female schools and came out with the following data having analyzed them in percentages.

Table 1: $\quad$ Analysis of SSCE Results in Economics between 1998 - 2002 (Mixed Schools)

\begin{tabular}{|l|l|l|l|l|l|l|}
\hline Years & $\begin{array}{l}(\mathrm{A} 1-\mathrm{A} 3) \\
\%\end{array}$ & $\begin{array}{l}(\mathrm{C} 4-\mathrm{C} 6) \\
\%\end{array}$ & $\begin{array}{l}\text { (A1 - C6) } \\
\%\end{array}$ & $\begin{array}{l}\text { (P7 } \\
\text { P8)\% }\end{array}$ & (F9) \% & $\begin{array}{l}\text { (P7 } \\
\text { F9)\% }\end{array}$ \\
\hline 1998 & 6.8 & 13.4 & 20.2 & 30.5 & 49.3 & 79.8 \\
\hline 1999 & 3.8 & 9.9 & 13.7 & 23.6 & 62.7 & 86.3 \\
\hline 2000 & 4.3 & 11.4 & 15.7 & 24.9 & 59.4 & 84.3 \\
\hline 2001 & 4.1 & 12.2 & 16.3 & 22.2 & 61.5 & 83.7 \\
\hline 2002 & 5.2 & 12.4 & 17.6 & 18.7 & 63.7 & 82.4 \\
\hline
\end{tabular}

Source: WAEC Research and Statistics Division 
From the above table column 3 and 6 are to be compared because columns 3 represents those who passed based on university requirements. This shows that at every year over $79 \%$ of students failed Economics while less that $21 \%$ passed the subject.

\section{Table 2: $\quad$ Analysis of SSCE Results in Economics between 1998 and 2002 (Male Schools)}

\begin{tabular}{|l|l|l|l|l|l|l|}
\hline Years & $\begin{array}{l}(\mathrm{A} 1-\mathrm{A} 3) \\
\%\end{array}$ & $\begin{array}{l}(\mathrm{C} 4-\mathrm{C} 6) \\
\%\end{array}$ & $\begin{array}{l}(\mathrm{A} 1-\mathrm{C} 6) \\
\%\end{array}$ & $\begin{array}{l}\text { (P7 } \\
\text { P8)\% }\end{array}$ & (F9) \% & $\begin{array}{l}\text { (P7 } \\
\text { F9)\% }\end{array}$ \\
\hline 1998 & 16.0 & 37.7 & 53.7 & 29.3 & 15.0 & 46.3 \\
\hline 1999 & 10.6 & 27.5 & 38.1 & 23.7 & 38.2 & 61.9 \\
\hline 2000 & 17.3 & 40.3 & 57.6 & 31.7 & 10.7 & 42.4 \\
\hline 2001 & 18.7 & 44.2 & 62.9 & 20.2 & 16.9 & 37.1 \\
\hline 2002 & 14.3 & 42.9 & 57.2 & 27.8 & 15.0 & 42.8 \\
\hline
\end{tabular}

Source: WAEC Research and Statistics Division

Table 3: Analysis of SSCE Results in Economics between 1998 and 2002 (Female Schools)

\begin{tabular}{|l|l|l|l|l|l|l|}
\hline Years & $\begin{array}{l}(\mathrm{A} 1-\mathrm{A} 3) \\
\%\end{array}$ & $\begin{array}{l}(\mathrm{C} 4-\mathrm{C} 6) \\
\%\end{array}$ & $\begin{array}{l}(\mathrm{A} 1-\mathrm{C} 6) \\
\%\end{array}$ & $\begin{array}{l}\text { (P7 - } \\
\text { P8)\% }\end{array}$ & (F9) \% & $\begin{array}{l}\text { (P7 } \\
\text { F9)\% }\end{array}$ \\
\hline 1998 & 15.4 & 30.8 & 46.2 & 26.5 & 27.3 & 53.8 \\
\hline 1999 & 8.3 & 19.5 & 27.8 & 29.0 & 43.2 & 72.0 \\
\hline 2000 & 17.6 & 31.5 & 49.1 & 28.5 & 22.4 & 50.9 \\
\hline 2001 & 15.7 & 39.0 & 54.2 & 26.6 & 18.7 & 45.3 \\
\hline 2002 & 16.7 & 41.7 & 58.4 & 30.6 & 11.0 & 41.6 \\
\hline
\end{tabular}

Source: WAEC Research and Statistics Division

Generally, there were more failures than passes especially in the mixed schools more than the single sexed schools. 
Analyzing the results of Table 2 above (male schools), it can be seen that their result was better when compared to other types of schools. The overall results within the period in review (1998-2002) have been poor when considered from the perspective that Economics is an interesting and easy subject as evident in the number of students that sat for it in the S.S.C.E. It can be observed that the difference in results of the total schools is not absolute but relative, because none of the schools can boast of $75-100 \%$ passes in any of the years in review.

\section{Statement of the Problem}

There has always been record of mass failure in economics in secondary schools. This may not be unconnected with teacher-centered method of teaching being used in our secondary schools. However, this research work is geared towards considering two Learner-Centered strategies for the study. The study sought to determine the effect of problem solving and concept mapping learning strategies on students' achievement.

\section{Literature Review}

Teaching Strategies

A strategy is the overall plan developed by a teacher to satisfy his instructional objectives. Every teacher uses both techniques and modes to achieve an instructional strategy. However, problem-solving and concept mapping strategies will be isolated for discussion in this paper. 


\section{Problem-Solving Strategies:-}

The problem-solving strategies have its roots in the inductive and deductive reasoning approach or the hypothetical-deductive learning models. It is involved in one common process. It facilitates the discovery of meaningful concepts, minimize memorization, and stress the importance of experience in solving a problem and arriving at warranted conclusion Meiring (1980) defined problem-solving as a form of discovery learning bridging the gap between learners existing knowledge and solution to the problem.

Mettes et al (1981) defined problem solving as a process of using information and reasoning to overcome obstacles and barrier.UNESCO (1986) considered problem solving as an approach of teaching under which such methods as inquiry, case, games, role play, simulation, research and discussion can be employed.

Problem solving is a by-product of learner knowledge of the concepts or ideas involved in a problem situation (conceptual knowledge) and also learner ability to take the right steps and decisions (procedural knowledge). A problem exists whenever there is a gap between where you are now and where you want to be and you do not know how to find a way to cross the gap. (Meltes 1981) problem solving teaching is the organization of teaching situation in which the students are confronted with that they have to solve with a certain amount of help.

When this approach in directed at solving a particular problem, it is generally referred to as problem-solving strategy. The procedure involve in this approach include.

1) There should be an identification of the problem, issue of question that requires an answer or solution 
2) The problem should be well defined and delimitation prescribed

3) Students should encourage to collect relevant data and other evidences that will help in solving the problem.

4) Collection of information on the problem (from people, library and any useful sources)

5) Analysis of the information (testing the hypothesis), this means you sift the information to remove irrelevant ones, ask further questions and arrange them to make meaning

6) Conclusion and application to new experience

7) Allow the class to discuss the findings

8) Summarize these findings

\section{Concept Mapping}

Concept mapping is a process or technique of representing concepts and their interrelationships in a twodimensional structure, showing the concepts in a topic /unit in their aches and inter connections. Concept mapping was developed by American Science educationist, Novak in 1974 provide a technique for representing knowledge in graphical or diagrammatic form with lines and phrases.

It is based on the modern theory of learning that knowledge is not isolated rather all knowledge age linked in a "wed form" through words and concepts. Words, ideas and concepts are the very ingredient critical to the formation of mental models.

\section{Uses of Concept Mapping}

1) Can be used to facilitate meaningful learning and as an evaluation tool. 
2) As a learning device, the teacher uses the concept map to enable the students to learn the meaning of the concepts and the relationship.

3) Learner-created concept maps can be used to summarize articles or chapter of textbook read.

4) It can be used to summarize a lesson and as tool to assess how the leaner understands and relates the concepts

Concept mapping allows the teacher to present in a holistic manner, all the basic information at a time. Areas of complex relationship are to a large extent simplified.

\section{Procedure for Constructing a Concept Map}

Step 1: Identify the concepts, principles, values or terms in a topic or a unit you want to cover.

Step 2: Organize these concepts in order of hierarchies with the specific ones subsumed under the more general ones

Step 3: Put the concept sin boxes or circles

Step 4: Use lines to show related concepts and "linking words" to give ideas about the relationship

\section{Research Hypotheses}

1) There is no significant main effect of treatment on students' achievement in Economics

2) There is no significant main effect of gender on students' achievement in Economics

3) There is no significant interaction effect of treatments and gender on students' achievement in Economics

\section{Methodology}

The research design employed a $3 \times 2$ pre-test, posttest, control group quasi experimental design. There are two experimental and two control groups. 
Relative Effects of Problem-Solving \& Concept Mapping ...

\section{Variables in the Study}

1) Independent Variable: The instructional strategies at three levels

i) Problem Solving

ii) Concept mapping

iii) Control group

2) Moderator Variable: Gender at two levels of

i) Male

ii) Female

3) Dependent Variable: Achievement in Economics

\section{Target Population}

The study covers some selected secondary schools in Ibadan South West Local Government area, Nigeria. The population of the study consisted of all the senior secondary school II students offering Economics. For the target population three schools were selected using random sampling method.

The selection of the schools was based on the following criteria.

1) They are all co-educational

2) The schools have been registering students for senior secondary school certificate examination in Economics for at least three years.

\section{Results}

The results of this study are presented as shown below. Summary of ANCOVA result and MCA result are presented on table 1 and 2 reference 
Table4: Summary of $3 \times 2$ Ancova of Post Test Economics Achievement According to Treatment and Gender

\begin{tabular}{|l|l|l|l|l|l|}
\hline Source of Variance & $\begin{array}{l}\text { Sum of } \\
\text { Square }\end{array}$ & DF & $\begin{array}{l}\text { Mean } \\
\text { Square }\end{array}$ & F & Sig. \\
\hline Post Covariate Pretest & 275.052 & 1 & 275.052 & 38.515 & .000 \\
\hline Main Effects Combined & 25.253 & 3 & 8.418 & 1.179 & .327 \\
\hline Treatment & 21.671 & 2 & 10.836 & 1.517 & .229 \\
\hline Sex & 3.582 & 1 & 3.582 & .502 & .482 \\
\hline $\begin{array}{l}\text { 2-Way Interaction } \\
\text { Treatment and Sex }\end{array}$ & 4.1178 & 1 & 4.1178 & .585 & .448 \\
\hline Model & 304.484 & 5 & 60.897 & 8.527 & .000 \\
\hline Residual & 357.070 & 50 & 7.141 & & \\
\hline Total & 661.554 & 55 & 12.028 & & \\
\hline
\end{tabular}

Significant at $\mathrm{P}<0.05$

Table 5: Multiple Classification Analysis of Post Test Economics Achievement by Treatment and Gender Grand Mean $=10.16$

\begin{tabular}{|l|l|l|l|l|l|}
\hline & $\mathrm{N}$ & Unadjusted & eta & $\begin{array}{l}\text { Adjust for Factors } \\
\text { and Covariates }\end{array}$ & Beta \\
\hline $\begin{array}{l}\text { Posttest Treatment: } \\
\text { Problem solving }\end{array}$ & 19 & -1081 & & .6199 &. \\
\hline Concept Mapping & 20 & -5607 & & -6812 & .159 \\
\hline Control & 17 & -7805 & .160 & .1085 & \\
\hline Sex Male & 35 & .7250 & & .2363 & .089 \\
\hline Female & 21 & -1.2083 & .272 & -.3938 & \\
\hline Multiple R. & .674 & & & & \\
\hline Multiple R. Square & .454 & & & & \\
\hline
\end{tabular}

\section{Hypotheses}

Ho1: There is no significant main effect of treatments on students' achievement in Economics

Table 4 show that there is no significant main effect of treatment on students achievement in Economics $\left(\mathrm{F}_{(2.50)}=\right.$ 1.517, $\mathrm{P}>$ >.05). This means that there is no significant difference in Economics achievement of students exposed to 


\section{Relative Effects of Problem-Solving \& Concept Mapping ...}

the problem solving, concept mapping and control. On this basis, the null hypothesis 1 is not rejected.

In order to find out the magnitude of the performance of students in each of the three treatment groups, the MCA from Table 5 shows that the problem solving group had a mean score of 10.78 and performed better than the control group that came $2^{\text {nd }}$ with a mean score of 10.27 . The concept mapping group had the least adjusted mean deviation of 9.48. These mean scores were obtained by adding up the adjusted deviations with the grand mean.

Ho2: There is no significant main effect of gender on students' achievement in Economics.

From table 4, it is obtained that the main effect of gender on students' achievement in Economics is not significant. $\left(F_{(1,50)}=.502 ; P>.05\right)$. This means that males do not differ significantly from females in the Economics achievement. Hence the null hypothesis 2 is not rejected. To find the magnitude of the mean scores, table 5 has shown that males obtained a higher adjusted mean than their female counterparts. $(x$ for male $=10.39, x$ for female $=9.77$ )

Ho3: There is no significant interaction effect of treatment and gender on students' achievement in Economics

Table 4 showed that the two way interaction effect of treatment and gender is not significant $\left(\mathrm{F}_{(1.50}=.585, \mathrm{P} 7.05\right)$. This led to the non-rejection of hypothesis 3 .

\section{Discussion of Result}

Result of the analysis showed that there was no significant main effect of treatments on student's achievement 
in Economics. This is at variance with other studies. Adu (2000) and, Ige (1998).Also students exposed to problem solving strategy perform better than those exposed to concept mapping and control (Though not significant). With adequate time for the implementation of the strategy, it is possible for the student to be more conversant with it because it is learner centered. This corroborates the findings of Adu (2002), Ige (1998), and Okoronka (2003).

\section{Recommendations}

On the basis of the discussion of result and general experience during the study, the following recommendations are considered necessary.

Teachers should be trained in the used of learner centered instructional strategies such as problem solving. The periodic use of such and other innovative strategies will promote high-level learning.

Teachers should pay attention to the training of their students in the development of problem solving skills before the end of SSCE Programme.

As the result obtained for gender, it may be necessary to carry out more research on factors other than teaching strategies which may influence the learning of boys and girls. Teachers who specialize in Economics should be taken the subject in schools.

\section{Conclusion}

This study sought to determine the effect of problem solving and concept mapping on students' achievement in Economics. These findings revealed that there was no 
significant main effect of treatments and gender on students' achievement in Economics.

Though the students performed better in problem solving strategy, teachers should endeavor to identify what constitutes problems in economics. Also the inability of students' to construct concept maps could be major bane of the strategy.

\section{References}

Abimbade, A.(1983):The Relative Effectiveness of Programmed Instruction to the Traditional Teaching of Secondary School Mathematics" M.Ed project, University of Ibadan.

Adu, E.O. (2002): Two Problem-Based Learning Strategies, Quantitative Ability and Gender as Determinants of Students Academic Achievement in economics. An unpublished Ph.D. Thesis. U.I. Ibadan

Ajiboye, J.O. (1985): "Emerging Method of Teaching" Paper Presented at the Department of Teacher Education, University of Ibadan. December.

Dada, A. (1991): "Method and Techniques of Teaching" Paper Presented at the National Workshop on Teaching Method. Institute of Education, University of Ibadan. November

Ezeokoli F.O. (1999): Conceptualization of Teaching" A Basis for Effective English Language Teaching Preparation for Post Modernism in Nigeria

Ishola P.L. (2000): Problem-Solving Instructional Strategies, Student Numerical Ability and Gender as determinant of Learning Outcomes in Senior Secondary Physics. Unpublished Thesis

Ituah, S.M. (2003). An Appraisal of Trends in Performances of Students in Economics at the School Certificate Examination. Unpublished B.Ed. Project submitted to Teacher Education Dept. U.I. 
Lawal, O. A. (1982). 'O' Level Economics of West Africa. Heinemann Educational Books Nig. Ltd.

Majasan J.A. (1995): The Teachers Profession. A manual for Professional Excellence, Ibadan, Spectrum Books Ltd.

Meltes, C.T. et al. (1981). Linking Factual and Procedural Knowledge in Solving Science Problems: A Case Study in Thermodynamic Courses. Instructional Science 10, 333 -

Meiring, S.P. (1980). Problem Solving: A Basic Goal becoming a better problem solver 2 A Resource for Problem Solving. Columbia department of education.

Obemeata, J.O. (1985). Examination of Claims that Economics is easy to pass in the W.A.S.C.E, in M.A. Mkpa, S.O. Olaitan, V. Nwachukwu, S.O. Ayodele (eds.). Issues in Curriculum Evaluation and Vocational Education in Nigeria. Curriculum organisation of Nigeria chapter 22.

Obemeata, J.O. (1992). Executive of Economics in Senior Secondary Schools. The West African Journal of Education. 1 (1), 9-13. Onimode, O.A. (1994). Effects of the Use of Formative Evaluation on some Cognitive Student learning outcomes in secondary mathematics Studies in Educational Evaluation. 20 (2), 223225.

Oyedeji O.A. (1998): Teaching for Innovation. Ibadan. Lade-Oje Publishers.

Okoronka U.A. (2003): Mode-based Instruction, Cognitive Style and Quantitative Ability as determinants of Students' Learning Outcomes in Secondary School Physics in Lagos State. Unpublished Post-field Seminar Paper. University of Ibadan.

Szrete, R. (1975). Economics Education. in schools in N. Lee (ed.). Teaching Economics; Heinemann Educational Books. 